\title{
$\mathrm{UF}$

\section{Southern Red Mite, Oligonychus ilicis (McGregor) (Arachnida: Acari: Tetranychidae) ${ }^{1}$}

\section{H. A. Denmark, W. C. Welbourn, and T. R. Fasulo² \\ Introduction}

The southern red mite (SRM), Oligonychus ilicis (McGregor) is an important spider mite pest of broad-leaved evergreens. Bolland et al. (1998) reported the SRM from from seven countries on four continents and feeding on 34 different plant species in 15 families. The SRM is called the coffee red mite in Brazil.

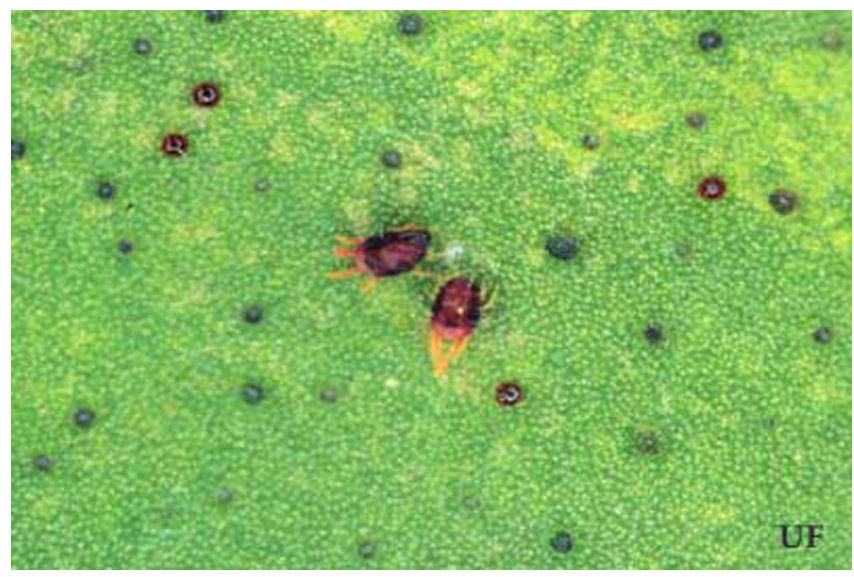

Figure 1. Adult southern red mites, Oligonychus ilicis (McGregor). Credits: R.F. Mizell, University of Florida

\section{Synonymy}

Oligonychus ilicis (McGregor) was originally described as Tetranychus ilicis by McGregor 1917, from American holly (Ilex opaca) in South Carolina. McGregor transferred the species to Paratetranychus in 1919 and Pritchard and Baker (1955) placed it in Oligonychus. The holotype is in the U.S. National Museum.

\section{Distribution}

The general distribution of the SRM includes the Northern Hemisphere and South America. Although the southern red mite was described in the United States, Pritchard and Baker (1955) suggested it might have originated in the "Far East." Published distribution records includes: Brazil, Italy, Japan, Korea, The Netherlands, Paraguay, and the USA. Although O. ilicis was reported from Australia (Knihinicki et al. 1999), the Australian Department of Agriculture, Fisheries \& Wildlife reports it as eradicated (Anonymous 2006).

1. This document is EENY-376 (IN680), originally published as DPI Entomology Circular 79, one of a series of Featured Creatures from the Entomology and Nematology Department, Florida Cooperative Extension Service, Institute of Food and Agricultural Sciences, University of Florida. Published: July 2006. This document is also available on Featured Creatures Website at http://creatures.ifas.ufl.edu. Please visit the EDIS Website at http://edis.ifas.ufl.edu.

2. H. A. Denmark and W. C. Welbourn, Florida Department of Agriculture and Consumer Services, Division of Plant Industry; and T. R. Fasulo, Department of Entomology and Nematology, University of Florida, Gainesville, FL. other services only to individuals and institutions that function with non-discrimination with respect to race, creed, color, religion, age, disability, sex, sexual orientation, marital status, national origin, political opinions or affiliations. U.S. Department of Agriculture, Cooperative Extension Service, University of Florida, IFAS, Florida A. \& M. University Cooperative Extension Program, and Boards of County Commissioners Cooperating. Larry Arrington, Dean 
In the United States the southern red mite has been reported from Alabama, California, Florida, Louisiana, Massachusetts, New Jersey, New York, North Carolina, Ohio, South Carolina, and Virginia. It is probably widespread on broad-leaved evergreens in the eastern United States.

\section{Description and Biology}

The adult female is approximately $385 \mu(1 / 50$ inch) in length with a rotund-elliptical body. The adult male is approximately $300 \mu$ in length, much less rotund, and narrowed posteriorly. The male aedeagus is shown below. Both sexes are ferruginous to reddish brown, and darker than most red spider mites found on woody ornamentals. It is more translucent towards the front end of the body (Mizell et al. 2002).

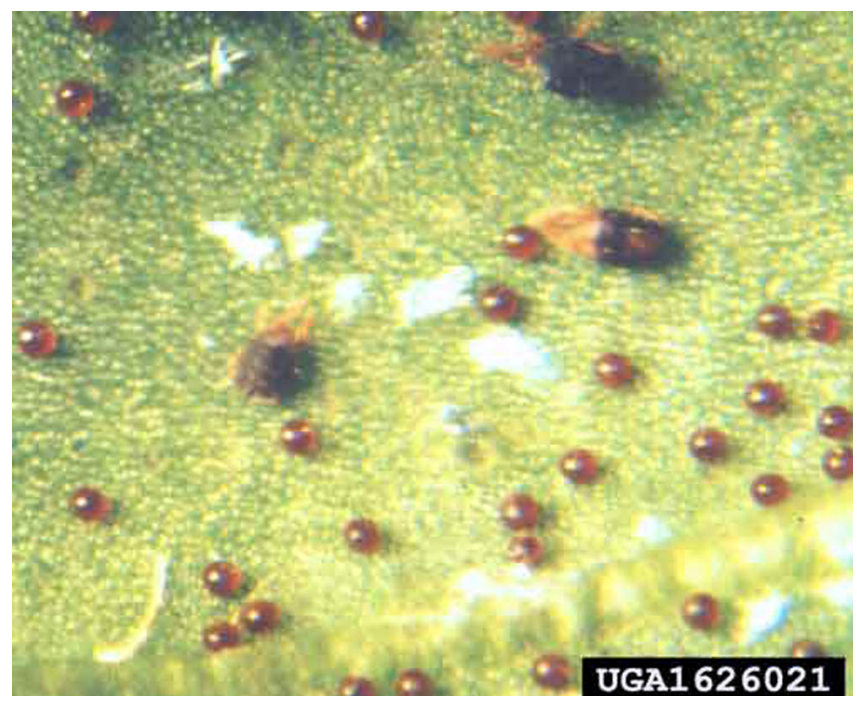

Figure 2. Eggs, nymphs, adults and cast skins of the Oligonychus ilicis (McGregor). Credits: Eric R. Day, Virginia Polytechnic Institute and State University; www.insectimages.org

Numerous generations occur each year, but population densities are highest during the cooler months of spring and fall during periods of prolonged high humidity. The species overwinters as red eggs on the undersides of the leaves. However, darker, summer eggs can be abundant on preferred hosts when infestations are not controlled. While some mites may be active during the summer months, most of the population is dormant (in aestivation) during the summer heat (Johnson and Lyon 1994).

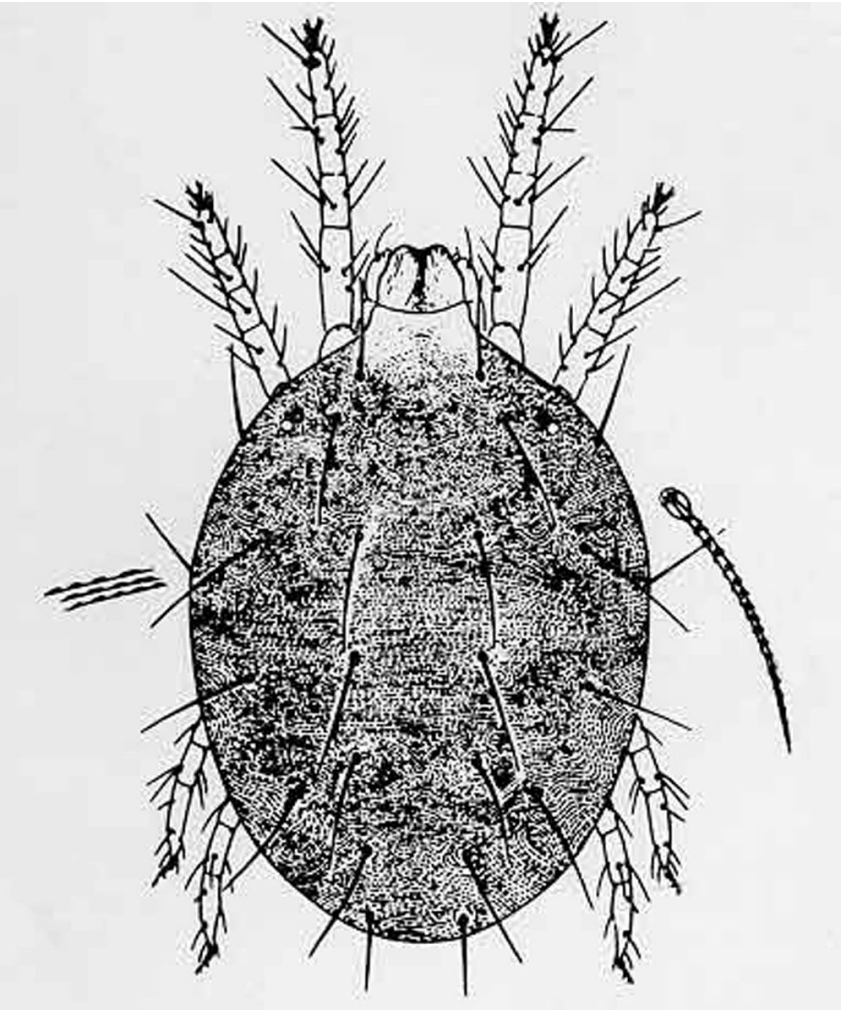

Figure 3. Adult female: dorsal view. Credits: J.L. Castner, University of Florida

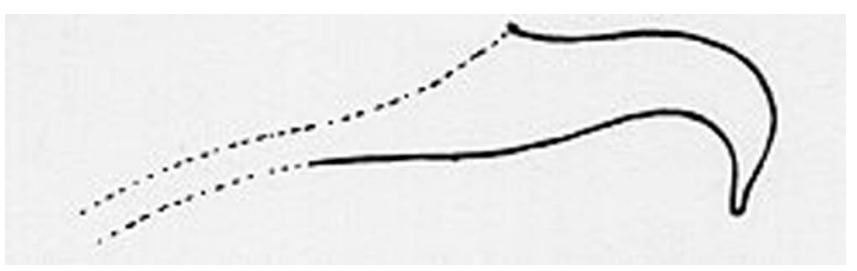

Figure 4. Male aedeagus.

\section{Hosts}

Common hosts are azaleas (Rhododendron spp.) and camellias (Camellia japonica).

Other reported host plants include: boxwood (Buxus spp.), tea (Camellia sinensis), pecan (Carya illinoensis), camphor tree (Cinnamonum camphora), summersweet or sweet pepperbush (Clethra alnifolia), coffee (Coffea arabica), cotoneaster (Cotoneaster sp.), elaeagnus or silverthorn (Elaeagnus pungens), laurel or bay leaf (Laurus nobilis), loquat (Eriobtrya japonica), eucalyptus (Eucalyptus spp.), silkoak (Grevillea robusta), hibiscus (Hibiscus spp.), holley (Ilex spp.), English walnut (Juglans regia), juniper (Juniperus sp.), doghobble (Leucothoe sp.), spruce (Picea sp.), photinia or red tip (Photinia spp.), American 
sycamore (Platanus occidentalis), guava (Psidium guajava), pyracantha (Pyracantha coccinea), pear (Pyrus communis), oak (Quercus sp.), deer grass or meadow beauty (Rhexia sp.), rose apple (Syzygium jambos =Eugenia), cranberry (Vaccinium macrocarpon), viburnum (Viburnum spp.).

\section{Economic Importance}

This mite feeds primarily on foliage of woody ornamental plants. It is particularly a pest of azaleas and camellias. It usually attacks the lower leaf surface and as the population increases it will move to the upper surface of the leaves and on to small succulent stems. It injures the leaves causing a graying, stippling or mesophyll collapse, "firing," and defoliation. The leaves may be distorted if infested occurs when they are young and expanding (Johnson and Lyon 1994).

Southern red mite populations are at their peak during the winter months under mild, humid conditions. These mites can be found year round in the landscape, especially on eleagnus and on shaded or stressed pyracantha. Populations in the nursery usually disappear when the new spring growth develops (Mizell et al.2002).

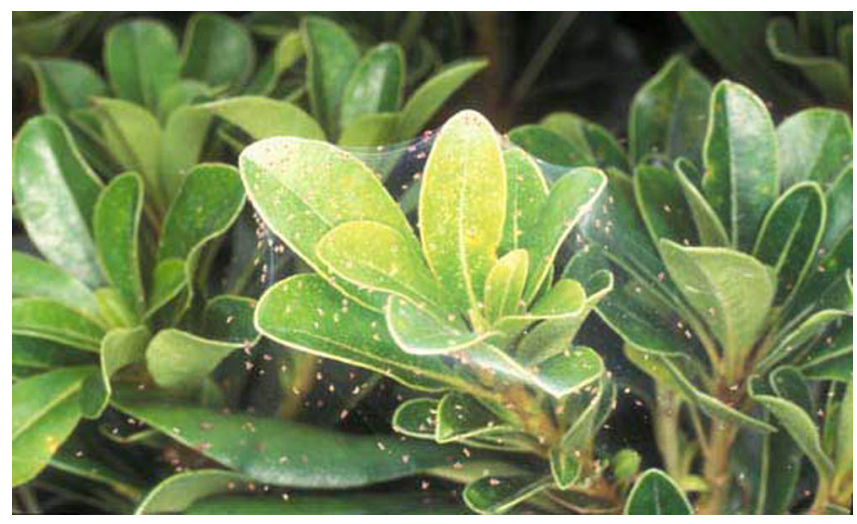

Figure 5. Damage caused by a southern red mite, Oligonychus ilicis (McGregor), infestation. Credits: J.L. Castner, University of Florida

\section{Management}

Use a $10 \mathrm{X}$ to $15 \mathrm{X}$ magnifying glass to examine the undersides of the leaves for the mites, cast skins and their webbing. A quicker method that many employ is to place a sheet of white paper or paper plate beneath the leaves and strike the foliage sharply. If mites are present they will fall onto the

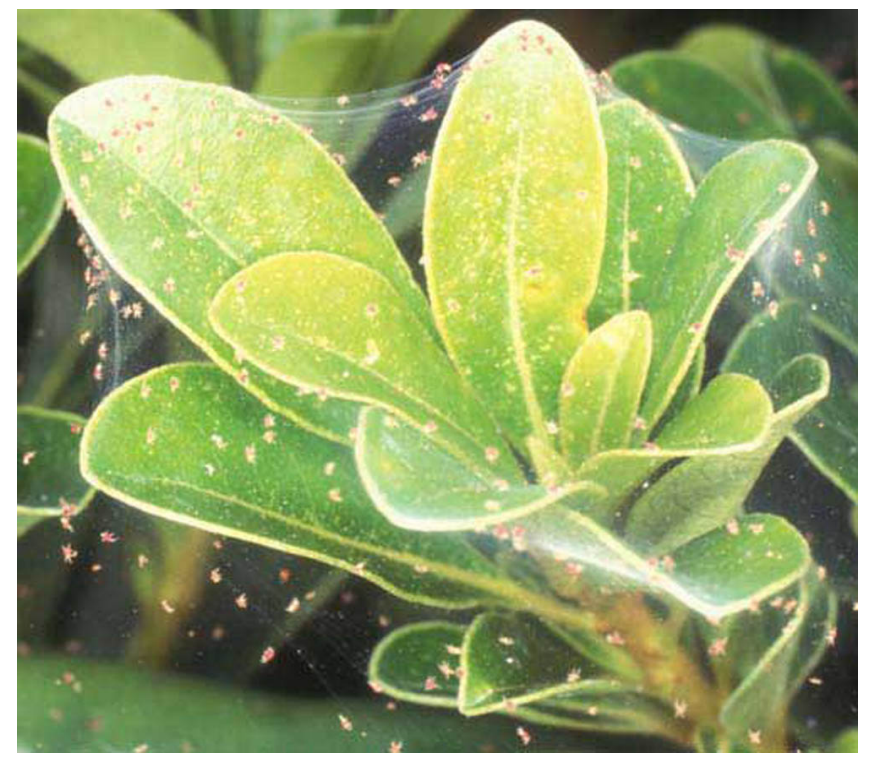

Figure 6. Damage caused by a southern red mite, Oligonychus ilicis (McGregor), infestation. Credits: J.L. Castner, University of Florida

white surface where they can be more easily seen and identified than on the green foliage.

For more information see Insect Management Guide for Ornamentals (http://edis.ifas.ufl.edu/ TOPIC_GUIDE_IG_Ornamentals).

[The junior author thanks Dr. R.F. Mizell, UF/IFAS ornanmental entomologist, for his review of this updated publication.]

\section{Selected References}

Anonymous. (2006). New Plant Pests and Diseases Recorded in Australia. Australian Government Department of Agriculture, Fisheries and Wildlife. (http://www.affa.gov.au/content/ output.cfm?ObjectID=84D90915-8340-434B9677E0D0B5C54D2F\#1999) (31 May 2006).

Bolland HR, Gutierrez J, Flechtmann CHW. 1998. World catalogue of the spider mite family (Acari: Tetranychidae). Brill Academic Publishers, Leiden, 392 pp.

Johnson WT, Lyon HH. 1994. Insects That Feed on Trees and Shrubs. An illustrated practical guide. 2nd ed. rev. Cornell University. Press, Ithaca, NY. $560 \mathrm{p}$. 
Knihinicki D, Keskula D, Herron G. (1999). The southern red mite: another new pest. The Nursery Papers. (http://www.ngia.com.au/publication resources/NP_Pdf/NP_1999-10.pdf) (31 May 2006).

McGregor EA. 1917. Descriptions of seven new species of red spiders. Proceedings of the U.S.

National Museum 51: 581-590.

Mineiro JLC, Sato ME, Raga A, Arthur V, Moraes GJ. Sarreta FO, Carrijo A. 2006. Diversity of mites (Arachnida: Acari) on Coffea arabica L. cv. Mundo Novo in Jeriquara and Garça counties, state of São Paulo. Biota Neotrop. 6: 2.

Mizell RF, Fasulo TR, Short DE. (2002). WoodyBug. UF/IFAS.

(http://woodypest.ifas.ufl.edu/) (14 September 2002).

Pritchard AE, Baker EW. 1955. A revision of the spider mite family Tetranychidae. Pacific Coast Entomological Society Memorandum 2: 472 p.

Reeves RM. 1963. Tetranychidae infesting woody plants in New York state, and a life history study of the elm spider mite, Eotetranychus matthyessei n. sp. Cornell University Agricultural Experiment Station, Memoir 380: 1-99. 